\title{
PERJANJIAN INTERNASIONAL TENTANG KESEPAKATAN MASYARAKAT EKONOMI ASEAN DAN TIONGKOK DALAM HUKUM NASIONAL INDONESIA
}

\author{
Jean Elvardi \\ Fakultas Hukum Universitas Andalas \\ Email: jean_elvardi@yahoo.com
}

\begin{abstract}
Indonesia's participation in international treaties can not be avoided in global situation, but it does not mean to exclude the national interest especially with regard the protection of Indonesian workers. The government must necessarily put the national interest as the main objective, and if the country is in unfavorable conditions even harming national interests, it should be evaluated or if necessary aborted.
\end{abstract}

\section{Kata Kunci: Perjanjian Internasional, Masyarakat Ekonomi Asean, Hukum Nasional}

\section{A. Latar Belakang}

Indonesia sebagai negara merdeka dan berdaulat memerlukan kerjasama internasional dengan negara-negara di berbagai belahan dunia. Agenda utama sebuah negara melakukan perjanjian internasional demi kepentingan nasional negara-negara itu. Indonesia telah melakukan perjanjian-perjanjian internasional dengan negara-negara kawasan, baik dengan negara-negara Asia Tenggara maupun dengan negara-negara lainnya di dunia. Dalam melakukan kerjasama dengan negara-negara lain, Indonesia mesti memahami secara mendasar, serta jelas, karena mempunyai akibat hukum pasca pengesahan perjanjian internasional.

Dalam Konsideran Undang-undang Nomor 24 Tahun 2000 tentang Perjanjian Internasional (selanjutnya disingkat UU No. 24 Tahun 2000), disebutkan bahwa pembuatan dan pengesahan perjanjian internasional antara Pemerintah Republik Indonesia dan pemerintah negara-negara lain, organisasi internasional, dan subjek hukum internasional lain adalah suatu perbuatan hukum yang sangat penting karena mengikat negara pada bidang-bidang tertentu, dan oleh sebab itu pembuatan dan pengesahan suatu perjanjian internasional harus 
dilakukan dengan dasar-dasar yang jelas dan kuat, dengan menggunakan instrumen peraturan perundang-undangan yang jelas pula.

Pernyataan pembuatan dan pengesahan suatu perjanjian yang dibuat harus dilakukan dengan dasar yang kuat dan menggunakan instrumen peraturan yang ada dalam hukum nasional Indonesia. Pengesahan sebagai suatu istilah sering disamakan dengan ratifikasi meski sebenarnya kedua istilah tersebut dalam konteks tertentu sering juga berbeda makna pengertiannya (Edy Suryono, 1984: 71). Penggunaan istilah pengesahan dalam UU No. 24 Tahun 2000 diadopsi dari istilah ratifikasi Konvensi Wina Tahun 1969, yang menyebutkan bahwa ratifikasi, penerimaan, pengesahan dan aksesi dalam setiap kasus diartikan sebagai tindakan internasional apapun namanya dimana suatu negara dalam taraf internasional membuat kesepakatannya untuk mengikatkan diri pada suatu perjanjian. Dengan demikian dalam praktik hukum perjanjian internasional di Indonesia penggunaan istilah pengesahan sama dengan ratifikasi, dan sebenarnya penggunaan kedua istilah tersebut sah-sah saja selagi tidak menjadi persoalan atau tidak mengaburkan atau tidak menyesatkan permasalahan, sebab dengan memaknai pengertian yang berbeda dapat menjadikan pemahaman yang berbeda pula, karena maknanya sangat luas (Michael Bogdan, 1994: 4).

Berdasarkan Pasal 14 Konvensi Wina Tahun 1969, ratifikasi merupakan suatu cara untuk mengikatkan diri dalam suatu perjanjian dan biasanya dimulai dengan melakukan penandatangan, dan ditentukan bahwa:

1. Kesepakatan sesuatu negara untuk mengikatkan diri terhadap perjanjian dinyatakan melalui ratifikasi apabila:

a. perjanjian itu sendiri memuat kesepakatan semacam itu yang dinyatakan melalui cara-cara ratifikasi;

b. jika tidak akan ditetapkan bahwa negara-negara perunding telah menyetujui bahwa ratifikasi memang diperlukan;

c. wakil dari negara telah menandatangani perjanjian, tetapi kemudian perjanjian itu harus diratifikasi; atau

d. ada kehendak dari negara untuk menandatangani perjanjian dan akan meratifikasi kemudian seperti yang tertulis di dalam kuasa penuh dari 
wakil-wakil negara tersebut atau dinyatakan selama perundingan berlangsung.

2. Kesepakatan dari suatu negara untuk mengikatkan diri pada perjanjian dinyatakan dengan cara-cara penerimaan atau pengesahan sesuai dengan syarat-syarat yang sama dengan semua yang diterapkan dalam ratifikasi.

Keseragaman dalam pemahaman ratifikasi sangat diperlukan, karena akan menyangkut sistem hukum dari banyak negara yang berbeda sistem hukumnya (common law dan civil law, termasuk negara-negara yang tidak sama dengan kedua sistem tersebut, misalnya Thailand, Rusia, Jepang, Tiongkok). Perbedaan cara pandang dan sistem ini bukan tidak mungkin akan menimbulkan perdebatan di kemudian hari dari para pihak.

Beberapa aturan perjanjian internasional tersedia di dalam Konvensi Wina Tahun 1969 (walaupun beberapa negara belum meratifikasinya termasuk Indonesia), tetapi hal itu tidak mempengaruhi karena pada dasarnya konvensikonvensi ini merupakan kodifikasi dari hukum kebiasaan internasional, sehingga tetap mengikat setiap negara dengan atau tanpa meratifikasinya (Damos Dumoli Agusman, 2010: 4). Setelah Konvensi Wina Tahun 1969 diterima, suatu negara juga membutuhkan adanya pengesahan atau ratifikasi sesuai konstitusi negara masing-masing, tetapi realitanya untuk meminta pengesahan atau ratifikasi seringkali juga membutuhkan waktu lama untuk memperolehnya (G.J.H. van Hoof, 2000: 244). Negara yang belum atau tidak meratifikasi akan tetap terikat sesuai ketentuan Pasal 3 Konvensi Wina Tahun 1969, tetapi keterikatan Indonesia adalah melalui mekanisme hukum kebiasaan internasional seperti dinyatakan oleh mahkamah internasional tahun 2002 (Damos Dumoli Agusman, 2010: 4), dengan demikian tidak ada alasan untuk tidak tunduk kepada Konvensi Wina Tahun 1969, karena secara normatif mengikat Indonesia.

Hukum nasional (konstitusi) Indonesia menentukan persetujuan (ditafsirkan dengan pengesahan) dengan negara lain diatur pada Pasal 11 UUD 1945, dengan demikian setiap undang-undang yang diusulkan dibuat harus melalui persetujuan Dewan Perwakilan Rakyat, sedangkan pengaturannya pada UU No. 24 Tahun 2000 apabila termasuk kategori yang mendapatkan persetujuan Dewan 
Perwakilan Rakyat diatur dalam Pasal 10 UUD 1945. Pengesahan perjanjian internasional ini masih tetap ada masalah, karena yang menjadi persoalan dalam UU No. 24 Tahun 2000 adalah bentuk pengesahan (ratifikasi) yang dilakukan dengan Undang-undang dan Keputusan Presiden.

Berdasarkan Pasal 10 UUD 1945, ada beberapa kategori pengesahan dengan undang-undang, yakni terkait masalah strategis, misalnya masalah politik, perdamaian, pertahanan dan keamanan negara, termasuk HAM dan lingkungan hidup. Sebaliknya masalah yang tidak termasuk kategori pada Pasal 10 UUD 1945 diatur dengan Keputusan Presiden, tetapi beberapa aturan yang telah diratifikasi Indonesia masih belum konsisten dan belum tertata dengan baik sesuai dengan keinginan undang-undang yang berlaku, walaupun Indonesia telah mengikatkan diri pada perjanjian internasional melalui cara dengan bentuk tersebut. Apabila diratifikasi dalam bentuk undang-undang akan menimbulkan penafsiran bahwa perjanjian internasional yang dilakukan dengan undang-undang sama dan setara kekuatan mengikatnya, tetapi dengan jenis dan hierarki peraturan perundanganundangan, maka dapat mengaburkan atau ketidakjelasan status dan kedudukan perjanjian internasional dalam sistem hukum nasional Indonesia.

Munculnya kesepakatan para pemimpin ASEAN (KTT ASEAN) pada bulan Desember 1997 di Kuala Lumpur (Malaysia) tentang pentingnya meningkatkan daya saing ASEAN, serta guna menyaingi negara Tiongkok dan India untuk menarik investasi asing. Untuk itu diperlukan adanya kesepakatan bersama bagi 10 (sepuluh) negara ASEAN dalam bermufakat dan kemudian hasil tersebut ditindaklanjuti pada pertemuan lanjutan pada Konferensi Tingkat Tinggi (KTT) ASEAN di Bali (Indonesia). Kemudian dideklarasikanlah pembentukan Masyarakat Ekonomi ASEAN (MEA) yang berlaku efektif Desember 2015. Beberapa dampak dari konsekuensi MEA adalah dampak aliran bebas arus investasi, aliran bebas barang, dampak arus bebas jasa, dampak arus tenaga kerja terampil serta dampak arus bebas modal. Pada kawasan ASEAN saja persaingan tenaga kerja Indonesia masih kalah bersaing. Padahal di era kompetitif sekarang ini, apalagi sejak berlakunya kesepakatan ASEAN tidak bisa dihindari persaingan tenaga kerja sangat ketat. Secara rill sebenarnya masyarakat (Organisasi 
Masyarakat Sipil) keikutsertaan Indonesia pada kesepakatan ASEAN masih menyisakan persoalan. Hal ini terkait dengan hukum nasional Indonesia yang menganggap kesepakatan itu bertentangan dengan UUD 1945.

Pemerintahan Indonesia sekarang ini banyak membuat kerjasama internasional terutama dengan Tiongkok. Apalagi sejak tahun 2010 ASEANTiongkok (CAFTA) telah ada kerjasama perdagangan, tetapi beberapa hal yang harus dihindari adalah masalah masuknya tenaga kerja asing asal Tiongkok yang tidak punya keahlian khusus. Padahal untuk tenaga kerja non terampil (non keahlian khusus/non skill labour) cukup menggunakan tenaga kerja lokal.

Persaingan tenaga kerja lokal maupun tenaga kerja asing rentan bermasalah bagi Indonesia. Hal ini karena kecemburuan masyarakat pribumi terhadap tenaga kerja asing asal Tiongkok yang notabene juga tenaga kerja kasar (non terampil). Akibatnya tenaga kerja lokal tersingkir (pembangunan pabrik Semen Merah Putih di Bayah, Lebak dan pabrik PT Conch South Kalimantan Cement di desa Serdang Kecamatan Haruai, Kabupaten Tabalong, Kalimantan Selatan). Padahal Indonesia hingga sekarang masih banyak tenaga kerja kasar yang masih tidak bekerja. Akibat keikutsertaan Indonesia pada Piagam Asean dan Tiongkok (CAFTA) secara otomatis akan terikat pada perjanjian internasional tersebut. Tidak itu saja kerjasama Indonesia dengan Tiongkok rentan konflik dengan penduduk lokal, akibat dari timbulnya persaingan antar sesama pencari kerja. Ada dugaan sebagai akibat perjanjian antara Indonesia dengan Tiongkok pada kesepakatannya memasukkan klausul penggunaan tenaga kerja (tenaga kerja non terampil) dari Tiongkok. Perjanjian seperti inilah yang perlu dikaji ulang atau pembatalan perjanjian kerjasama karena merugikan kepentingan nasional

Perjanjian internasional pada kawasan ASEAN (Treaty Charter) yang diikuti Indonesia masih menimbulkan perdebatan, karena selain merugikan kepentingan nasional juga dianggap bertentangan dengan UUD 1945, tetapi pada Piagam ASEAN (Treaty Charter) belum menjelaskan cara-cara apabila negara anggota (member state) atau negara peserta Piagam ASEAN (Treaty Charter) tentang pengunduran diri (withdrawal). Hal ini tentunya perlu dianalisis, terutama 
dalam kaitannya dengan suatu pertanyaan: "apakah kepentingan nasional Indonesia terakomodir dalam perjanjian internasional tersebut?"

\section{B. Perjanjian Internasional Indonesia pada Kesepakatan Masyarakat Ekonomi ASEAN dan Tiongkok.}

Perjanjian internasional merupakan salah satu sumber hukum internasional yang merupakan kehendak bersama (kehendak negara) serta untuk tujuan bersama. Seiring dengan perkembangan hukum internasional yang semakin kompleks maka perjanjian internasional juga menghadapi tantangan baru. Untuk menghindari ketidakpastian hukum negara-negara untuk melakukan hubungan kerjasama maka kejelasan aturan-aturan terkait dengan perjanjian internasional menjadi kebutuhan mendesak. Meningkatnya jumlah perjanjian internasional antar negara dalam zaman sekarang dinyatakan oleh G.I. Tunkin, sebagaimana dikutitip (I. Wayan Parthiana, 2002: 3), bahwa: “secara proporsional perjanjian internasional pada masa kini menduduki tempat yang utama dalam hukum internasional sebagai akibat munculnya secara meluas persetujuan-persetujuan internasional."

Indonesia setelah berakhirnya Orde Baru telah melakukan perjanjian internasional dengan banyak negara-negara kawasan, baik dengan negara-negara Asia Tenggara maupun dengan negara-negara maju di dunia ini. Tujuan perjanjian adalah untuk kepentingan kedua belah pihak baik Indonesia maupun negara yang melakukan perjanjian internasional dengan Indonesia, seperti dinyatakan dalam Alinea Pertama Pembukaan Undang Undang Dasar 1945.

Negara merupakan suatu lembaga, yaitu suatu sistem yang mengatur hubungan yang ditetapkan oleh manusia antara mereka sendiri sebagai satu alat untuk mencapai tujuan yang paling pokok, antara lain, sebuah sistem ketertiban yang menaungi manusia dalam melakukan kegiatan (J.L. Brierly, 1996: 97). Dalam aturan hukum internasional meski tidak ditemukan pengertian negara akan tetapi dalam Pasal 1 Konvensi Montevideo Tahun 1933 telah mensyaratkan adanya sebuah negara, tetapi dalam perkembangannya, terdapat perbedaan pandangan dan interpretasi tentang pengertian negara berdaulat dan negara tidak 
berdaulat. Negara sebagai subjek hukum internasional yang utama merupakan suatu kumpulan komunitas individu yang memiliki kedaulatan, kemerdekaan dan sejajar dengan negara-negara lain di dunia ini. Artinya suatu negara memiliki kewenangan sendiri dan tidak boleh diintervensi urusan domestiknya oleh negara negara lain. Dengan kata lain bahwa suatu negara, lazim dianggap bebas dan berdaulat hanya terhadap atau di dalam wilayahnya sendiri (Yudha Bhakti Ardhiwisastra, 1999: 47). Negara dikatakan berdaulat atau "soverign" karena negara itu mempunyai kekuasaan tertinggi, walaupun kekuasaan tertinggi ini mempunyai batas-batasnya. Ruang kekuasaan tertinggi di batasi oleh batas-batas negara itu, artinya suatu negara memiliki kekuasaan tertinggi di dalam batas wilayahnya (Mochtar Kusumaatmaja dan Etty. R. Agoes, 2003: 16).

Kedaulatan merupakan kekuasaan tertinggi yang di miliki oleh sebuah negara untuk secara bebas melakukan berbagai kegiatan sesuai dengan kepentingannya sepanjang tidak bertentangan dengan kaidah hukum internasional yang ada. Kedaulatan merupakan kekuasaan tertinggi yang dimiliki suatu negara sebagaimana negara lain juga memiliki hak kedaulatan yang sama bahkan kedudukannya setara bagi setiap negara. Dalam Piagam PBB ditegaskan lagi bahwa: "the equal rights of ...... nations large and small". Pada kesempatan lain dalam Piagam PBB pada Pasal 21 dinyatakan: "the Organization is based on the Principle of the sovereign equality of all its members". Prinsip ini direfleksikan dalam pemberian satu suara bagi satu anggota Majelis Umum PBB, prinsip ini dikuatkan lagi dalam Deklarasi mengenai Prinsip-prinsip Hukum Internasional tahun 1970 yang menyatakan: "setiap negara memiliki kesamaan kedaulatan, mereka memiliki kesetaraan hak dan kewajiban, juga kesetaraan sebagai anggota organisasi internasional, tanpa mempertimbangkan adanya perbedaan ekonomi, sosial, politik, dan sifat lainnya" (Jawahir Thontowi dan Pranoto Iskandar, 2006: 115), dan secara khusus, kesetaraan kedaulatan mencakup elemen-elemen (Jawahir Thontowi dan Pranoto Iskandar, 2006: 115):

1. Negara-negara adalah secara yuridis sederajat.(States are juridical equal).

2. Setiap negara memiliki hak-hak inheren kedaulatan penuh (each State enjoys the rights inherent in full sovereignty). 
3. Setiap negara memiliki kewajiban untuk menghormati integritas negara lain (each State has the duty to respect the personality of other State).

4. Integritas wilayah dan kemerdekaan politik suatu negara tidak dapat dicampuri (the territorial integrity and political independence of the State are inviolable).

5. Setiap negara memiliki kebebasan untuk memilih dan mengembangkan sistem politik, budaya, sosial, dan ekonomi (each State has the right freely to choose and develop its political, social, economic, and cultural system).

6. Setiap negara mempunyai kewajiban untuk memenuhi tuntutan secara penuh dengan itikad baik menurut kewajiban internasional yaitu, untuk hidup berdampingan secara damai (each State has the duty to comply fully and in good faith with its international obligations and to live and to live in peace with other State).

Prinsip diatas memcerminkan kesamaan dan kesetaraan setiap negara dalam melakukan hak dan kewajibannya dalam hukum internasional. Di antara negara-negara di dunia, juga ada negara yang tidak dapat melakukan hubungan internasional dengan negara lain, sehingga belum dapat disebut sebagai negara berdaulat, karena dalam hukum internasional kedaulatan memiliki 3 (tiga) aspek utama (Boer Mauna, 2002: 24), yaitu:

1. Aspek ekstern kedaulatan adalah hak bagi setiap negara untuk secara bebas menentukan hubungannya dengan berbagai negara atau kelompok - kelompok lain tanpa kekangan, tekanan, atau pengawasan dari negara lain.

2. Aspek intern kedaulatan adalah hak dan wewenang eksklusif suatu negara untuk menentukan bentuk-bentuk lembaga-lembaganya, cara kerja lembagalembaganya tersebut dan hak untuk membuat undang-undang yang diinginkannya, serta tindakan-tindakan untuk mematuhi.

3. Aspek territorial kedaulatan adalah berarti kekuasaan penuh dan eksklusif yang dimiliki oleh negara atas individu-individu dan benda-benda yang terdapat di wilayah tersebut.

Intinya sebuah negara yang disebut negara berdaulat adalah negara yang mampu membuat suatu keputusan akhir tanpa dipengaruhi pihak atau otoritas lain, 
dan memperjuangkan haknya untuk menentukan keputusan akhir tanpa harus mematuhi kehendak otoritas lain (Mirza Satria Buana, 2007: 34). Negara bebas melakukan tindakan yang menurut negara tersebut sah dilakukan selama tidak bertentangan atau mengganggu ketentraman dan keamanan negara lain dan tidak melanggar aturan-aturan hukum internasional, sehingga kedaulatan yang dimiliki negara bukanlah suatu pengertian kedaulatan yang absolut melainkan pengertian kedaulatan relatif (G.P.H. Djatikoesoemo, 1956: 27).

Sebaliknya Hegel sebagaimana dikuti (G.P.H .Djatikoesoemo, 1956: 27), menyatakan bahwa kehendak negara adalah kepentingan negara, negara adalah ketertiban hukum yang tertinggi, kedaulatan ini tidak mengenal batas. Dalam praktiknya, masyarakat internasional banyak mengambil jalan kompromis dimana kedaulatan negara yang absolut tidak mungkin dipersatukan dalam hukum internasional. Hanya saja perlu adanya kesesuaian antara keduanya sepanjang tidak mengintervensi kedaulatan negara. Kedaulatan yang diserahkan oleh hukum internasional ini masih dapat dikurangi dengan mengadakan persetujuanpersetujuan dimana mereka saling menentukan kewajiban-kewajiban, tetapi pengurangan tersebut tidak akan dikurangi jika negara itu tunduk pada keputusan pengadilan internasional untuk menyerahkan suatu penyusunan hukum pada alatalat internasional dengan tidak memakai ketentuan-ketentuan apa-apa, karena negara itu telah ada di bawah hukum internasional. Pernyataan tersebut tentu berakibat akan menghilangkan kemandirian negara dalam wilayah kedaulatannya. Negara dianggap tidak lagi berdaulat apabila negara tersebut menyerahkan kebijaksanaan luar negerinya pada negara lain, maka menurut ukuran-ukuran yang berlaku negara ini dapat dikategorikan negara tidak berdaulat atau tidak lagi berdaulat (G.P.H. Djatikoesoemo, 1956: 26).

Pasal 1 ayat (2) Piagam PBB tidak ada kalimat tegas menyatakan kriteriakriteria negara dianggap tidak berdaulat, hanya menyangkut penentuan nasib sendiri (self determination). Piagam PBB hanya menyebutkan sebagai tujuannya, yaitu mengembangkan hubungan persahabatan antara bangsa-bangsa berdasarkan penghargaan atas prinsip-prinsip persamaan hak, dan hak rakyat untuk menentu- 
kan nasib sendiri, dan mengambil tindakan-tindakan yang wajar untuk memperteguh perdamaian universal.

Kedaulatan yang dimiliki oleh setiap negara merupakan lambang (emblem) kekuasaan tertinggi yang dipunyai oleh setiap negara yang bebas dan merdeka. Konsekuensi yang muncul dari adanya kekuasaan yang tertinggi ini adalah kekuasaan tersebut tidak dapat dilaksanakan tanpa menafikan adanya kekuasaan yang juga dimiliki oleh negara lain. Dalam hubungan internasional, prinsip persamaan kedaulatan merupakan dasar dari masyarakat internasional untuk melaksanakan aktifitas kegiatan antar negara seperti dinyatakan dalam Pasal 2 ayat (1) Piagam PBB, bahwa: organisasi bersendikan pada prinsip-prinsip persamaan kedaulatan dari semua Anggota, dan menurut (Boer Mauna, 2002: 25) kedaulatan negara tersebut tidak selamanya mempunyai pandangan positif, tetapi juga negatif, sebagai berikut:

1. Kedaulatan dalam arti negatif, bahwa negara tidak tunduk pada ketentuanketentuan hukum internasional yang statusnya lebih tinggi. Kedaulatan berarti negara tidak tunduk pada kekuasaan apapun dan dari manapun datangnya tanpa persetujuan negara yang bersangkutan.

2. Kedaulatan dalam arti positif, memberikan kepada titulernya yaitu negara pimpinan tertinggi atas warga negaranya. Ini yang dinamakan wewenang penuh dari suatu negara. Kedaulatan memberikan wewenang kepada negara untuk mengeksploitasi sumber-sumber daya alam dalam wilayah nasional bagi kesejahteraan umum masyarakat banyak. Ini yang disebut kedaulatan permanen atas sumber-sumber kekayaan alam.

Menurut Ian Brownlie (1998: 78), dikatakan bahwa kedaulatan suatu negara amat tergantung dengan posisi negara tersebut dalam hubungannya dengan negara yang mendukungnya, dan kedaulatan mempunyai arti yang sama dengan kemerdekaan (Earlier it was stated that as state remains "independent", in the sense of retaining separate personality). Dengan demikian, suatu negara merdeka berarti berdaulat dan sebaliknya berdaulat berarti merdeka. Bagi suatu negara yang baru lahir dan yang mengadakan kegiatan hubungan luar negeri disebut negara merdeka atau negara berdaulat. Kata merdeka lebih diartikan bahwa suatu 
negara tidak lagi di bawah kekuasaan asing dan bebas untuk menentukan kebijaksanaan dalam dan luar negerinya dan kata kedaulatan lebih mengutamakan kekuasaan eksklusif yang dimiliki negara tersebut dalam melaksanakan kebijaksanaannya (Boer Mauna, 2002: 25).

Negara yang bebas dari tekanan dan intervensi negara lain dikategorikan negara yang berdaulat, tetapi dilihat dari beberapa konvensi dan Piagam PBB tidak ada menyebut pengertian negara termasuk kategori negara berdaulat. Hanya saja beberapa ahli hukum internasional menyatakan tentang pengertian negara, sebagai berikut (http//www.org.online):

1. Roger. F. Soltou menyatakan negara adalah alat atau wewenang yang mengatur atau mengendalikan persoalan bersama atas nama masyarakat.

2. Djokosoetono menyatakan negara adalah suatu organisasi manusia atau kumpulan manusia yang berada di bawah suatu pemerintahan yang sama.

3. Francois Rigoux menyatakan negara adalah suatu masyarakat daerah yang mempunyai hak bertindak, sedang pemerintahannya merupakan kekuasaan yang tertinggi untuk penduduk yang bertempattinggal di daerah itu.

4. Dalam Black's Law Dictionary dinyatakan: State: the political system of a body of people who are politically organized; the system of rules by which jurisdiction and authority are exercised over such a body of people (separation of church and state).

Berdasarkan beberapa pendapat di atas, defenisi tersebut hanya diberikan pada negara yang punya hak kedulatan dan merupakan suatu organisasi kekuasaan yang mempunyai wewenang dalam wilayah tertentu, tetapi suatu negara disebut berdaulat apabila didapat suatu masyarakat hukum yang mempunyai 3 (tiga) buah kompetensi, yaitu dengan sifat-sifat pribadi, "zakelijk"dan territorial, dan yang mengatur kompetensi-kompetensi alat-alatnya di dalam batas-batas yang dibuat oleh ketertiban hukum bangsa (G.P.H. Djatikoesoemo, 1956: 25).

Seperti telah dinyatakan di atas, belum ada kesepakatan tentang pengertian negara, walaupun sebenarnya ahli hukum internasional mencoba membuat tentang pengertian negara. Selanjutnya Beleefroid sebagaimana dikutip Azyumardi Azra (2004: 34) mendefinisikan negara sebagai "suatu masyarakat hukum yang 
menempati suatu wilayah tertentu dan yang di lengkapi dengan kekuasaan tertinggi untuk kepentingan umum”. Hal ini dipertegas F. Sugeng Istanto (2010: 29), yang mengatakan bahwa yang dimaksudkan negara adalah yang memenuhi syarat yakni: pemerintah dan kemampuan untuk mengadakan hubungan internasional.

Negara sebagai sebuah subjek hukum internasional yang utama merupakan suatu kumpulan komunitas individu yang memiliki kedaulatan, kemerdekaan dan sejajar dengan negara-negara lain. Ini menggambarkan bahwa tidak satupun negara dapat diintervensi kedaulatannya, artinya suatu negara memiliki kewenangan mereka masing-masing dan tidak boleh satu sama lain mencampuri urusan domestik negara lain. Negara bebas melakukan segala tindakan yang menurut negara tersebut sah dilakukan selama tidak bertentangan atau mengganggu ketentraman dan keamanan negara lain dan tidak melanggar aturanaturan hukum internasional (Mirza Satria Buana, 2007: 58).

Seringkali perjanjian internasional dibuat dengan negara yang tidak memenuhi persyaratan di atas hanya karena alasan potensi yang dimiliki oleh negara tersebut menguntungkan kepentingan nasional. Ke depan, analisis terhadap situasi objektif terkait kedaulatan sebuah negara perlu ditingkatkan agar tidak merugikan pemerintah Republik Indonesia, walaupun dalam regulasi telah termuat pernyataan memperhatikan baik hukum nasional dan hukum internasional yang berlaku, sebagaimana tertuang dalam Pasal 4 ayat (2) UU No. 24 Tahun 2000, bahwa "dalam pembuatan perjanjian internasional, Pemerintah Republik Indonesia berpedoman pada kepentingan nasional dan berdasarkan prinsip-prinsip persamaan kedudukan, saling menguntungkan, dan memperhatikan, baik hukum nasional maupun hukum internasional yang berlaku".

Pernyataan di atas menegaskan pentingnya kepentingan nasional serta melihat prinsip-prinsip kesetaraan kedudukan, saling menguntungkan dengan memperhatikan hukum baik nasional maupun internasional. Prinsip persamaan atau kesetaraan (equality before sovereign state) terletak pada titik sentral dalam hukum maupun hubungan internasional. Prinsip ini terlihat dengan jelas bagi penganut teori positif atau konsensualisme yang sangat menekankan pada 
pentingnya persetujuan dari negara-negara sebelum sebuah hukum dapat berlaku (Jawahir Thontowi dan Pranoto Iskandar, 2006: 114). Setelah itu prinsip yang ada pada setiap perjanjian internasional secara universal yang disetujui, dilaksanakan dengan sebaik-baiknya, serta dengan itikad baik (good faith) berdasarkan prinsip atau aturan yang telah disepakati (Pasal 26 Konvensi Wina Tahun 1969).

Dalam membuat perjanjian internasional beberapa pandangan secara tegas mendefenisikan bahwa pentingnya tujuan dibuatnya perjanjian tersebut karena menyangkut konsekuensi yang diterima negara yang telah membuat persetujuan perjanjian, seperti ditegaskan bahwa perjanjian internasional merupakan suatu perjanjian yang diadakan antara masyarakat bangsa-bangsa dan bertujuan untuk mengakibatkan akibat-akibat hukum tertentu (Mochtar Kusumaatmaja sebagaimana dikutip Edi Suryono, 1984: 12).

Berbeda dengan pandangan di atas, Konvensi Wina Tahun 1969 justru menekankan pentingnya perjanjian internasional dibuat secara tertulis dan perjanjian yang dibuat secara lisan tidak dapat dimasukkan ke dalam jenis perjanjian internasional, walaupun perjanjian internasional yang bersifat lisan melahirkan kewajiban internasional (Edi Suryono, 1984: 12), sebagaimana mana tertuang dalam Pasal 2 Konvensi Wina Tahun 1969, bahwa: "treaty means an international agreement concluded between states in written form and governed by international law, whether embodied in a single instrument or in two or more related instruments and whatever its particular designation".

Oppenheim-Lauterpacht justru menegaskan perjanjian adalah suatu persetujuan antar negara, yang menimbulkan hak dan kewajiban di antara para pihak. Pihak yang dimaksud adalah negara yang merupakan subjek utama di dalam hukum internasional. Dengan demikian secara umum dapat dikatakan bahwa ciriciri suatu perjanjian internasional adalah dibuat oleh subjek hukum internasional, pembuatannya diatur oleh hukum internasional dan akibatnya mengikat subjeksubjek yang menjadi pihak (Boer Mauna, 2002: 82).

Setiap perjanjian internasional memerlukan penandatangan dan pengesahan dari negara yang melakukan perjanjian, dan perjanjian internasional merupakan perjanjian antar negara dengan tujuannya mempunyai akibat hukum 
tertentu bagi pihak yang membuatnya. Perjanjian internasional merupakan bukti autentik negara melakukan kerjasama dengan negara lainnya, serta dilengkapi bukti tertulis.

Dalam sejarahnya Mahkamah Internasional Permanen (PCIJ) pernah mengeluarkan keputusan yang mengeluarkan keputusan yang menerima sengketa antara Norwegia dan Denmark dalam kasus Greenland dikenal dengan "Ihlen Declaration" tahun 1919 dan menerima perjanjian oral sebagai perjanjian yang mengikat negara yang melakukan perjanjian. Keputusan Mahkamah Internasional tersebut telah membawa akibat hukum bahwa perjanjian internasional secara lisan atau tertulis dalam hukum internasional adalah sama. Kalau dilihat putusan Mahkamah Internasional ada beberapa cara pengambilan keputusan yang mesti diketahui para pihak untuk berperkara (J.L. Brierly, 1996: 227).

Putusan Mahkamah didahului sebelumnya dengan acara pemeriksaan tertulis (written proceding) dan acara pemeriksaan lisan (oral proceding). Putusan diambil berdasarkan pemungutan suara di antara hakim-hakim yang bersidang dan dilakukan secara rahasia, serta ditetapkan berdasarkan suara mayoritas. Oleh karena itu, dapat terjadi bahwa putusan itu diambil tidak secara aklamasi, dan dalam hal ini hakim yang tidak setuju terhadap putusan tersebut atau mempunyai alasan lain, maka kepada hakim-hakim itu diberi hak untuk menyatakan pendapatnya secara terpisah (Abdul Rasjid, 1985: 63).

Keputusan Mahkamah Internasional diambil dengan suara mayoritas dari hakim-hakim yang hadir, dan apabila ada suara yang seimbang maka suara Ketua atau Wakilnya sangat menentukan, karena bila terjadi suara yang sama, maka suara Pimpinan Mahkamah merupakan keputusan akhir yang dapat diambil untuk finalisasinya, sedangkan untuk pernyataan atau pendapat yang terpisah diperbolehkan sepanjang sengketa tersebut menimbulkan adanya pandangan yang berbeda dari para hakim. Pandangan yang terpisah ini dikenal dengan pendapat terpisah (dissenting opinion), artinya para hakim yang tidak setuju dengan putusan Mahkamah dapat menyatakan pendapat yang berbeda (Boer Mauna, 2002: 255).

Putusan yang telah diambil dalam pemungutan suara tersebut harus ditandatangani oleh Presiden Mahkamah Internasional dan Panitera, setelah itu 
harus dibacakan dalam sidang terbuka untuk umum, serta diberitahukan kepada pihak yang berperkara. Putusan Mahkamah Internasional bersifat akhir (final) dan tidak ada upaya banding kecuali kalau ada penafsiran tentang putusan itu. Penafsiran dimaksud agar pihak yang berperkara dapat memahami isi Putusan Mahkamah Internasional secara utuh dan dipahami para pihak. Kenyataan ini agar tidak terjadi perbedaan penafsiran terhadap putusan seperti kasus antara Columbia dan Peru dalam kasus Haya de la Torre, sebagai konsekuensi Putusan Mahkamah Internasional.

Kenyataan demikian menunjukkan bahwa walaupun Putusan Mahkamah Internasional bersifat final, tetapi masih memungkinkan adanya "upaya revisi" peninjauan kembali terhadap Putusan Mahkamah Internasional jika ada terdapat sesuatu hal yang menemukan fakta-fakta baru yang di kemudian hari dan fakta itu sesuatu hal yang sangat menentukan dan hal ini baru diketahui kemudian setelah adanya putusan serta merupakan kekeliruan Mahkamah Internasional. Upaya untuk melakukan revisi ini dapat diajukan kepada Mahkamah Internasional dalam batas waktu 6 (enam) bulan sejak diketemukan adanya fakta yang demikian (Pasal 61 Statuta Mahkamah Internasional).

Demikian pula untuk menghindari subjektivitas, keputusan yang diambil para hakim Mahkamah Internasional harus terdiri dari 15 orang hakim, yang diambil dari beberapa warganegara yang berbeda serta wilayah yang berbeda sesuai dengan geografis negaranya (Pasal 61 Statuta Mahkamah Internasional), tetapi apabila suatu negara tidak memiliki hakim yang berasal dari negaranya, maka diperkenankan memilih seorang hakim ad hoc (Sefriani, 2010: 348). Dalam tugasnya di Mahkamah Internasional para hakim bukan mewakili negaranya dan keanggotaan Mahkamah adalah berupa wakil dari bagian terbesar masyarakat internasional dan mewakili sistem hukum utama sejauh tidak bertentangan dengan pengadilan lain (J.G. Starke, 2007: 652).

Mahkamah Internasional bukan merupakan organ antar pemerintah dan hakim-hakim internasional tersebut juga wakil pemerintahnya yang dapat bertindak sesuai dengan instruksi-instruksi pemerintahnya masing-masing. Sehingga untuk menjaga kemandirian hakim, para hakim mempunyai kekebalan- kekebalan 
seperti halnya Pejabat Diplomatik (Pasal 19 Statuta Mahkamah Internasional), sedangkan selama dalam menjalankan fungsinya para hakim tidak boleh menjalankan fungsi yang lain sebelum berakhir masa jabatannya, serta tidak boleh menjalankan kegiatan profesi yang biasa dilakukan sebelum hakim tersebut menjadi hakim Mahkamah Internasional (Pasal 16 Statuta Mahkamah Internasional). Para hakim mahkamah juga dilarang menjadi penghubung perkara yang dapat menyebabkan hakim tidak mandiri atau menjadi wakil dimana dia sebelumnya turut serta mengambil bagian dalam perkara tersebut baik secara langsung maupun tidak langsung (Pasal 17 Statuta Mahkamah Internasional).

Terkait dengan keikutsertaan Indonesia pada masyarakat ekonomi ASEAN sangat penting melihat sumber daya manusia Indonesia, agar siap berkompetisi dengan negara-negara di kawasan ASEAN. Indonesia sebagai salah satu negara penduduk terbesar dan punya wilayah yang besar sangat menguntungkan bagi negara di sekitarnya, tetapi untuk ikut kompetisi sesama negara di kawasan ASEAN, Indonesia sepertinya belum siap berkompetisi, mengingat masih lemahnya sumber daya manusia Indonesia khususnya persiangan tenaga kerja. Hak ini terbukti dari tenaga kerja yang ke luar negeri masih dalam kualitas pembantu rumah tangga atau pekerja kasar.

Bila melihat kehadiran ASEAN sebagai suatu kawasan yang terintegrasi dalam bidang ekonomi di kawasan Asia Tenggara, maka harus dipahami 4 (empat) hal yang menjadi titik fokus yang dapat dijadikan momentum yang baik dilakukan Indonesia (Arya Baskoro, http://crmsindonesia.org), yaitu:

1. Negara-negara di kawasan Asia Tenggara ini dijadikan sebuah wilayah kesatuan pasar dan basis produksi. Dengan terciptanya kesatuan pasar dan produksi maka arus barang dan produksi dan lain-lainnya tidak menjadi hambatan dari satu negara ke negara lainnya.

2. Masyarakat ekonomi ASEAN sebagai kawasan ekonomi memerlukan kebijakan yaitu kebijakan kompetisi (competition policy), hak kekayaan intelektual (intellectual property right), pajak (taxation) dan e-commerce. Tujuannya adalah demi untuk persaingan yang adil dan perlindungan hak cipta. 
3. Masyarakat ekonomi ASEAN yang dijadikan sebagai kekuatan perkembangan ekonomi yang merata akan memproritaskan unit usaha kecil (UKM), maka daya saing unit usaha kecil akan ditingkatkan.

4. Masyarakat ekonomi ASEAN akan dintegrasikan secara penuh terhadap perekonomian global

Terkait dengan investasi negara Tiongkok pada pemerintahan sekarang ini sudah sungguh mengkhawatir, terutama persaingan tenaga kerja Indonesia dengan tenaga kerja Tiongkok, dan sampai sekarang tidak jelas telah berapa banyak masuk tenaga kerja asing asal Tiongkok ke Indonesia, bahkan dari berbagai versi telah terjadi secara besar-besaran masuknya tenaga kerja kasar Tiongkok ke Indonesia (Yusril Ihza Mahendra mensinyalir sudah jutaan orang). Sebenarnya data tersebut telah dibantah oleh Kementerian Tenaga Kerja Indonesia, tetapi perlu ditelusuri perjanjian internasional Indonesia dengan Tiongkok terkait dengan klausul persyaratan yang mengharuskan penggunaan tenaga kerja kasar yang didatangkan dari negara asalnya Tiongkok. Kesepakatan antara pemerintah Indonesia dan Tiongkok yang merugikan kepentingan nasional harus di hindarkan. Sewajarnya Kementerian Luar Negeri mempelajari perjanjian antara Indonesia dan Tiongkok terkait investasinya di Indonesia.

\section{Penutup}

Kerjasama antara negara mestinya melahirkan keuntungan bagi kedua belah pihak. Semua negara meletakkan kepentingan nasional merupakan tujuan utama dan merupakan sesuatu yang amat penting. Apabila negara mengalami kondisi yang kurang menguntungkan apalagi merugikan kepentingan nasional, maka selayaknya dievaluasi atau bila perlu dibatalkan. Keikutsertaan Indonesia pada perjanjian internasional tidak bisa dihindari di tengah situasi global, tetapi tidak berarti mengenyampingkan kepentingan nasional, terutama perlindungan tenaga kerja Indonesia.

Tenaga kerja terampil Indonesia masih sulit bersaing dengan tenaga kerja asing, dan untuk itulah perjanjian internasional yang dibuat harus memperhatikan kepentingan nasional. Terkait Kementerian Tenaga Kerja Indonesia, Pemerintah 
Daerah bahkan kalau perlu pihak swastapun selayaknya dalam melakukan perjanjian internasional melibatkan Kementerian Luar Negeri Indonesia, tujuannya agar tidak merugikan kepentingan nasional Indonesia.

Kerjasama internasional antara Indonesia dengan Tiongkok harus jelas (term aggrement) nya. Hindari perjanjian yang merugikan kepentingan nasional, jangan muncul anggapan investasi Tiongkok tidak membawa implikasi apapun bagi perluasan lapangan kerja bagi rakyat Indonesia. Bahkan dapat dianggap merugikan Indonesia. Indonesia mesti belajar dari membanjirnya tenaga kerja kasar (buruh) Tiongkok masuk negara Angola (Afrika), Zimbabwe, dan Sri Langka. 


\section{DAFTAR PUSTAKA}

\section{Buku:}

Abdul Rasjid. 1985. Upaya Penyelesaian Sengketa Antar Negara Melalui Mahkamah Internasional. Surabaya: Bina Ilmu.

Boer Mauna. 2002. Hukum Internasional, Pengertian Peranan dan Fungsi dalam Era Dinamika Global. Bandung: Alumni.

Brierly, J.L. 1996. The Law of Nations an Introduction to the International Law of Peace. Oxford: University Press.

Brownlie, Ian. 1998. Principles of Public International Law. Oxford: Clarendon Press.

Bryan A. Garner. 1999. Black's Law Dictionary, Seven Edition, Editor in Chief, St. Paul-Minn: West Group.

Edi Suryono. 1984. Praktek Ratifikasi Perjanjian Internasional di Indonesia. Bandung: Remadja Karya.

Huala Adolf. 1994. Masalah-masalah Hukum Perdagangan Internasional. Jakarta: PT RajaGrafindo Persada.

1997. Hukum Ekonomi Internasional, Suatu Pengantar. Jakarta: PT RajaGrafindo Persada.

-. 2006. Hukum Penyelesaian Sengketa Internasional. Jakarta: Sinar Grafika.

-. 2007. Dasar-dasar Hukum Kontrak Internasional. Bandung: Refika Aditama.

Jahawir Thontowi dan Pranoto Iskandar. 2006. Hukum Internasional Kontemporer. Bandung: Rafika Aditama.

Kelsen, Hans. 2008. Pengantar Teori Hukum. (Terjemahan dari Introduction to The Problems of Legal Theory. Bandung: Nusa Media.

Mirza Satria Buana. 2007. Hukum Internasional Teori dan Praktek. Banjarmasin: FH Unlam Press.

Mochtar Kusumaatmaja. 1990. Pengantar Hukum Internasional. Bandung: Binacipta.

Nair, Mc. 1961. The Law of Treaties. Oxford: Clarendon Press.

Sefriani. 2010. Hukum Internasional Suatu Pengantar. Jakarta: Rajawali Press.

Starke, J.G. 2007. Introduction to International Law. Penerjemah Bambang Iriana Djajaatmadja. Jakarta: Sinar Grafika. 
Sugeng Istanto, F. 2010. Hukum Internasional. Jogyakarta: Atmajaya University Press.

Sumaryo Suryokusumo. 2008. Hukum Perjanjian Internasional. Jakarta: TataNusa.

Wayan Parthiana, I. 2005. Hukum Perjanjian Internasional. Bagian Pertama. Bandung: Mandar Maju.

Whisnu Situni, F.A. 1989. Identifikasi dan Reformulasi Sumber-sumber Hukum Internasional. Bandung: Mandar Maju.

Yudha Bhakti Ardhiwisastra. 1999. Imunitas Kedaulatan Negara di Forum Pengadilan Asing. Bandung: Alumni.

---------. 2003. Hukum Internasional Bunga Rampai. Bandung: Alumni.

\section{Jurnal:}

Francois Rigoux. 1997. "Issues of Politics, Law, and Economy", Journal of International Relations. Republic of Slovenia: Faculty of Social Sciences.

----------. 2000. “Aspek-Aspek Hukum Internasional Kontemporer”, Ius Quia Iustum.

Martin Dixon \& Robert Mc. Corquodale. 1995. "Cases \& Materials On International Law", British Library Cataloguing in Publication Data, Second Edition.

\section{Peraturan Perundang-undangan}

Republik Indonesia, Undang Undang Dasar Tahun 1945.

Republik Indonesia, Undang-undang Nomor 24 Tahun 2000 tentang Perjanjian Internasional. 


\section{BIODATA PENULIS}

$\begin{array}{ll}\text { Nama } & \text { : Dr. Jean Elvardi, S.H., M.H } \\ \text { Pekerjaan } & : \text { Dosen Fakultas Hukum Universitas Andalas } \\ \text { Jabatan } & : \text { Lektor Kepala } \\ \text { Nomor HP } & : 08126725461 \\ \text { E-mail } & : \text { jean_elvardi@yahoo.com } \\ \text { Alamat Kantor } & : \text { Kampus Fakultas Hukum Universitas Andalas, Limau Manis, }\end{array}$ Kec. Pauh, Padang, Telp. 0751-72985. 